\title{
Assessment of Occupational Exposure to Organic Solvents, Applied Safety Measures and Their Effect on Liver Function of Exposed Workers in Rubber Industry Tanta City - Gharbia Governorate
}

\author{
ZINAB M. ELGHMRY, M.Sc.; RANIA M. EL-SALLAMY, M.D.; IBRAHIM A. KABBASH, M.D. and \\ HAGRAS ELMURSI HAGRAS, M.D. \\ The Department Public Health and Community Medicine, Faculty of Medicine, Tanta University, Egypt
}

\begin{abstract}
Background: In rubber manufacturing, health hazards from organic solvents are due to their metabolic conversion to more hazardous substances which may lead to liver injury.

Aim of the Work: To measure indoor environmental exposure to some organic solvents, to assess applied safety measures in the workplace and to investigate liver function of occupationally exposed workers.

Subjects and Methods: This study was a cross sectional study conducted on rubber factoey production departments in the period from July 2017 up to October 2018. The study included 120 workers. Interview questionnaire with exposed workers and filling an audit workplace observational checklist by the researcher were used as tools of the study. Measuring environmental indoor exposure to some volatile organic compounds (benzene, toulene, ethylbenzene and xylene) was done by gas chromatography (GC). Liver function tests for exposed workers were measured.
\end{abstract}

Results: Environmental monitoring revealed higher levels of exposure to benzene, ethylbenzene and toluene $(2.13,560$ and $380 \mathrm{mg} / \mathrm{m}^{3}$ respectively), while level of xylene was within normal. The mean total score percent for checklist of applied safety measures was $17.94 \%+7.93 \%$. The study indicated lack of training programs with no periodic medical examination was made for workers. The majority of workers had occupational exposures to chemicals, fumes and dust $(70.8 \%, 73.3 \%$ $\& 60 \%$ ) respectively. Liver function tests were found to be normal in the majority of workers $(93 \%)$.

Conclusion and Recommendations: There were insufficient applied safety measures in the factory $\&$ increased levels of benzene, ethylbenzene and toluene more than the permissible exposure limits. So, regular environmental monitoring, applying the standard safety measures, and periodic medical examinations for workers are needed.

Key Words: Organic solvents - Liver function - Rubber industry workers.

Correspondence to: Dr. Zinab M. Ramadan Elghmry, E-Mail address: zinabelghmry90@gmail.com

\section{Introduction}

RUBBER is derived from both natural and synthetic sources. Natural rubber comes from diagonal incision in the tree trunk named "Hevea braziliensis" where latex is extracted from it and coagulated by adding acid. While synthetic rubber ( $70 \%$ of rubber) is obtained by mixing products of cracking process of crude oil with chemicals to make latex. International Agency for Research on Cancer (IARC) classified rubber industry as group 1 carcinogenic to humans since 1987. Rubber manufacturing faces various potential health hazards among exposed workers due to the harmful substances used in the chemical reactions in the process of manufacturing as well as hazards arising from rubber wastes and emissions [1]

In rubber manufacturing, there are multiple occupational exposures to dust and to a variety of volatile organic compunds "VOCs" as benzene, toluene and xylene $[2,3]$. Health hazards of these compunds are due to their metabolic conversion to more hazardous substances in liver which may cause organ injury including liver. Multiple factors may increase hepatotoxicity risk as long duration of exposure without use of personal protective equipment, obesity, drugs and genetic factors [3].

Clinical picture of occupational liver disease may be acute, subacute or chronic. Liver steatosis is a good clinical marker for solvent hepatotoxicity. The main pathological mechanisms responsible for solvent induced functional and organic damage are: cytochrome $\mathrm{P} 450$ dysfunction, mitochondrial dysfunction, inflammation and oxidative stress [2] Three conditions must be present for diagnosis of occupational toxic hepatitis [4,5]: (1): Liver damage occur after occupational exposure to a hepatotoxic 
substance, (2): Increased hepatic enzymes at least to double the upper limit of normal levels and (3): Exclusion of other causes of liver disease. Elevation of serum enzymes as alanine aminotransferase (ALT) and aspartate aminotransferase (AST) reflects hepatic parenchymal cells damage. Bilirubin, bile salts and proteins such as albumin and clotting factors are indicators of liver dysfunction [6].

The specific objectives of the present study were to measure environmental work place exposure to some organic solvents, to assess applied safety measures in the work place and to investigate liver function of workers occupationally exposed to organic solvents in rubber factory.

\section{Subjects and Methods}

A cross sectional study was carried out on all twelve production departments of the Tanta rubber factory. The factory production departments included (medium pressure hoses, profiles, radiator hoses, molded, battery cases, latex gloves, rubber lining, high pressure hoses, mixing, boilers, quality \& maintenance). Data were collected from July 2017 to October 2018.

All workers in all production departments of rubber factory (120 workers), who were available during the period of the study and accepted to participate, were our study participants. Workers in administrative departments, workers with history of liver disease before engagement into this factory and those who spent less than 2 years at work were excluded from the study.

The study tools were a predesigned structured questionnaire sheet filled by researcher through direct personal interviews with workers including socio-demographic data, present occupational history, past occupational history and current medical condition (Tool I).

Measurements of liver enzymes level: Aspartate transaminase and Alanine transaminase (AST \& ALT) were done for 114 workers who agreed to give blood samples. Two milliliters of blood were collected from each subject by venipuncture under aseptic condition and were left to clot. Blood samples were stored at $\pm 4^{\circ} \mathrm{C}$ in ice box, then centrifuged for serum preparation. Measurement of other liver functions as blood albumin level, total blood bilirubin level \& blood prothrombin time by the same procedure was done for workers with elevated liver enzymes (Tool II). A modified workplace observation checklist based on occupational safety and health administration (OSHA) standards and international labor office standards (ILO) was filled by the researcher to check applied safety measures at work place (Tool III) [7,8] . Environmental monitoring of workplace by measuring the level of some Volatile Organic Compounds "VOCs" in the most polluted rubber production department (mixing department) was carried out by the National Research Centre " in Giza, Egypt " according to the international requirements developed by NIOSH during whole shift working hours ( 8 hours). VOCs were collected using activated charcoal tubes (ORBOTM-32 activated coconut charcoal 20/40) and air was drawn through the charcoal tubes, using vaccum pumps calibrated to draw $1 \mathrm{~L} / \mathrm{min}$. After sampling time, the charcoal tubes were removed from the sampling train and two open sides were tightly closed using special caps to avoid any desorption then the samples were put into special plastic bags that were tightly closed and kept at $10^{\circ} \mathrm{C}$ in a freezer until processed. Sample analysis was done by Hewlett-Packard gas chromatography (GC) for solvents, fitted with a flame ionization detector (FID). Measured organic solvents were (benzene, toluene, ethylbenzene and xylene) (BTEX) (Tool IV) [9].

Ethical consideration: Approval from the ethical committee of Tanta Faculty of Medicine was obtained before starting the study. Subjects were informed about the purpose and procedures of the study. Oral consent and approval were obtained from each subject to participate in the study. Confidentiality and privacy were guaranteed during the whole period of the study.

Statistical analysis of data: Data was statistically analyzed by using SPSS-V21. Numerical data was presented as mean and standard deviation (SD) and categorical data was presented as number and percentage. Parametric tests were applied for normally distributed data such as ANOVA. For categorical variables, Chi-square test was used for analysis and when it was found inappropriate, it was replaced by Fisher's and Monte Carlo exact tests.

\section{Results}

The sample included 120 workers with a mean age of $38.62 \pm 7.36$ years. The majority of workers (94.2\%) were married. Most workers (80.8\%) were from rural areas. Regarding educational level, $83.4 \%$ of workers had secondary level of education and only $10 \%$ percent had university level (Table 1). Mean years of experience in current job was $11.83 \pm 4.77$. Technicians represented the most of workers $(79.1 \%)$. Regarding occupational exposures, most workers $(83.3 \%)$ reported exposure to heat, $77.5 \%$ exposed to noise and $73.3 \%$ exposed 
to fumes. While exposure to chemicals \& dust were reported by $70.8 \%, 60 \%$, respectively. Workers who had previous jobs before engagement to work in current job were $39.2 \%$ with $17 \%$ of them had similar previous chemical exposure (Table 2). Benzene, ethylbenzene, toluene and xylene were measured and revealed higher levels of 2. 13, 560 and $380 \mathrm{mg} / \mathrm{m} 3$, respectively. While level of xylene was within the accepted level $(307 \mathrm{mg} / \mathrm{m} 3)$ (Table $3)$. Workers reported that pre-employment medical examination was done to $95.8 \%$ of them with no periodic medical examination. Workers who were trained on safe work practice and on dealing with fire accidents were only $10.8 \%$. While, only $3.3 \%$ of workers reported training on dealing with emergency situations (Table 4). It was found that the mean total score percentage for all items of checklist of safety measures in all departments of the rubber factory was very low $(17.49 \% \pm 7.93 \%)$. The total mean score percentages for worksite in general and for fire protection were $42.59 \pm 19.44$ and $40.91 \pm 17.12$, respectively. Total percentage score for hazardous materials was $38.1 \pm 17.58$. For other items, the total percentage scores were very low ranging from zero for personal protective equipment to $26.32 \pm 16.34$ for machine guarding (Table 5). Six workers out of 120 workers refused to give blood samples.Liver enzymes were measured with eight workers $(7 \%)$ had elevated ALT level and Two workers had elevated AST level. Only two workers had both enzymes elevated. Other liver function tests as total blood bilirubin, serum albumin and prothrombin time revealed normal values (Table 6).

Table (1): Socio-demographic characteristics of studied workers.

\begin{tabular}{|c|c|c|}
\hline $\begin{array}{l}\text { Socio-demographic } \\
\text { characteristics }\end{array}$ & $\begin{array}{l}\text { Number } \\
(n=120)\end{array}$ & $\begin{array}{l}\text { Percent } \\
\%\end{array}$ \\
\hline \multicolumn{3}{|l|}{ Age in years: } \\
\hline $20-$ & 12 & 10.0 \\
\hline $30-$ & 56 & 46.7 \\
\hline $40-$ & 40 & 33.3 \\
\hline $50-60$ & 12 & 10.0 \\
\hline Range & \multirow{2}{*}{\multicolumn{2}{|c|}{$\begin{array}{c}22-60 \\
38.62 \pm 7.36\end{array}$}} \\
\hline Mean \pm SD & & \\
\hline \multicolumn{3}{|l|}{ Marital status: } \\
\hline Single & 6 & 5.0 \\
\hline Married & 113 & 94.2 \\
\hline Divorced & 1 & 0.8 \\
\hline \multicolumn{3}{|l|}{ Residence: } \\
\hline Rural & 97 & 80.8 \\
\hline Urban & 23 & 19.2 \\
\hline \multicolumn{3}{|l|}{ Educational level: } \\
\hline Illiterate & 3 & 2.5 \\
\hline Primary & 5 & 4.1 \\
\hline Secondary & 100 & 83.4 \\
\hline University & 12 & 10.0 \\
\hline
\end{tabular}

Table (2): Work related data of studied workers.

\begin{tabular}{|c|c|c|}
\hline Variables & $\begin{array}{l}\text { Number } \\
(\mathrm{n}=120)\end{array}$ & $\begin{array}{c}\text { Percent } \\
\%\end{array}$ \\
\hline \multicolumn{3}{|l|}{$\begin{array}{l}\text { Years of experience } \\
\text { in current job: }\end{array}$} \\
\hline$<5$ & 6 & 5.0 \\
\hline $5-$ & 22 & 18.3 \\
\hline $10-$ & 78 & 65.0 \\
\hline $15-$ & 8 & 6.7 \\
\hline $20+$ & 6 & 5.0 \\
\hline Range & \multicolumn{2}{|c|}{$2-34$} \\
\hline Mean \pm SD & \multicolumn{2}{|c|}{$11.83 \pm 4.77$} \\
\hline \multicolumn{3}{|l|}{ Type of job: } \\
\hline Production worker & 2 & 1.7 \\
\hline Guard worker & 3 & 2.5 \\
\hline Fire fighter & 1 & 0.8 \\
\hline Maintenance worker & 2 & 1.7 \\
\hline Observer & 4 & 3.3 \\
\hline Technician & 95 & 79.1 \\
\hline Chemist & 5 & 4.2 \\
\hline Department head & 8 & 6.7 \\
\hline \multicolumn{3}{|l|}{ Occupational exposures: } \\
\hline Chemicals & 85 & 70.8 \\
\hline Dust & 72 & 60.0 \\
\hline Fumes & 88 & 73.3 \\
\hline Heat & 100 & 83.3 \\
\hline Noise & 93 & 77.5 \\
\hline $\begin{array}{l}\text { Previous jobs with similar } \\
\text { chemical exposures }\end{array}$ & 8 & 17.0 \\
\hline
\end{tabular}

Table (3): Concentration of some VOCs in the environment of the rubber factory.

\begin{tabular}{lcc}
\hline VOCs & Concentration & Standard Limit (10) \\
\hline Benzene $(\mathrm{mg} / \mathrm{m} 3)$ & 2.13 & 1.6 \\
Ethylbenzene $(\mathrm{mg} / \mathrm{m} 3)$ & 560 & 434 \\
Toulene $\left(\mathrm{mg} / \mathrm{m}^{3}\right)$ & 380 & 188 \\
Xylene $\left(\mathrm{mg} / \mathrm{m}^{3}\right)$ & 307 & 434 \\
\hline
\end{tabular}

Table (4): Available safety measures in the factory as reported by the studied workers.

\begin{tabular}{lcc}
\hline Variables & $\begin{array}{c}\text { Number } \\
(\mathrm{n}=120)\end{array}$ & $\begin{array}{c}\text { Percent } \\
\%\end{array}$ \\
\hline $\begin{array}{l}\text { Pre-employment medical } \\
\text { examination }\end{array}$ & 115 & 95.8 \\
$\begin{array}{l}\text { Periodic medical examination } \\
\text { Use of protective equipment }\end{array}$ & 0 & 0.0 \\
$\begin{array}{l}\text { Training on safe manipulations } \\
\text { and safe work practice }\end{array}$ & 13 & 1.7 \\
$\begin{array}{l}\text { Training on dealing with fire } \\
\text { accidents }\end{array}$ & 13 & 10.8 \\
$\begin{array}{l}\text { Training on dealing with } \\
\text { emergencies }\end{array}$ & 4 & 3.3 \\
\hline
\end{tabular}


Table (5): The mean total score percentage for checklist items of safety measures.

\begin{tabular}{lll}
\hline Item & Range & Mean \pm SD \\
\hline Workplace in general & 66.67 & $42.59 \pm 19.44$ \\
Fire protection & 63.64 & $40.91 \pm 17.12$ \\
Hazardous materials & 57.14 & $38.10 \pm 17.58$ \\
Personal protective equipment, & .00 & .00 \\
$\quad$ ventilation \& records & & \\
Environmental conditions & 33.33 & $17.59 \pm 10.00$ \\
Hazardous chemical exposure & 22.73 & $13.26 \pm 6.84$ \\
First aid requirements & 50.00 & $17.50 \pm 13.57$ \\
Emergency response & 33.33 & $16.67 \pm 17.41$ \\
Electrical safety work practices & 14.29 & $5.36 \pm 5.38$ \\
Machine guarding & 52.63 & $26.32 \pm 16.34$ \\
\hline Total score percent & 26.85 & $17.94 \pm 7.93$ \\
\hline
\end{tabular}

Table (6): Liver enzymes \& other liver function tests of studied workers.

\begin{tabular}{|c|c|c|c|c|}
\hline \multirow{2}{*}{ Liver enzymes } & \multicolumn{2}{|c|}{$\operatorname{AST}(n=114)$} & \multicolumn{2}{|c|}{$\operatorname{ALT}(n=14)$} \\
\hline & $\mathrm{N}$ & 96 & $\mathbf{N}$ & 90 \\
\hline Normal & 112 & 98.2 & 106 & 93 \\
\hline Elevated & $2 *$ & 1.8 & 8 & 7 \\
\hline Other tests & \multicolumn{2}{|c|}{ Mean \pm SD } & \multicolumn{2}{|c|}{ Normal range } \\
\hline Total blood bilirubin in $\mathrm{mg} / \mathrm{dl}$ & \multicolumn{2}{|c|}{$0.64 \pm 0.1$} & \multicolumn{2}{|c|}{ up to $1 \mathrm{mg} / \mathrm{dl}$} \\
\hline Serum albumin level in $\mathrm{mg} / \mathrm{dl}$ & \multicolumn{2}{|c|}{$4.1 \pm 0.57$} & \multicolumn{2}{|c|}{$3.5-5.5 \mathrm{mg} / \mathrm{dl}$} \\
\hline Prothrombin time in sec & \multicolumn{2}{|c|}{$12.17 \pm 1.03$} & \multicolumn{2}{|c|}{$11-14 \mathrm{sec}$} \\
\hline
\end{tabular}

\section{Discussion}

Many chemicals are used to create the necessary properties of the final rubber product. The most important chemicals are organic solvents $[2,3]$. Long term heavy solvent exposure is hazardous to the liver [11]. Regarding environmental workplace exposure to some organic solvents, the present study revealed higher levels of benzene, ethylbenzene and toluene, while level of xylene was within the acceptable level. A study made by Lee $\mathrm{N}$ et al., [12] on Korean tire manufacturing found that polycyclic aromatic hydrocarbons were within the standard limit.

The present study found that majority of workers were not trained on safe manipulations with the chemicals or on dealing with fire accidents which is consistent with the study done by El Hamid Hassan et al., [12] that was performed on 92 male workers exposed to organic solvents in paint factory in Zagazig, Egypt and revealed insuf- ficient knowledge about the safe manipulations with commonly used solvents. Personal protective equipment "PPE" is one of the basic protective measures. The current study found that masks and gloves were used by only $(1.7 \%)$ of workers. R.Vermeulen et al., [14] in Netherlands reported increased use of PPE especially gloves $(45 \%)$ by exposed workers. This difference may be due to their high knowledge and positive attitude on importance of safe manipulations with chemicals.

The current study revealed that only $6.7 \%$ of workers had elevated ALT level and $1.7 \%$ of workers had elevated AST level. The effect of exposure to organic solvents on liver enzymes of the exposed workers is controversial. Some studies revealed a significant effect on liver function $[\mathbf{1 5}, \mathbf{1 6}]$ while, other studies didn't $[17,18]$. The results of the current study are similar to a study done by El Mahdy\& Radwan [19] on 68 workers occupationally exposed to mixture of organic solvents in painting industry in Cairo, Egypt and revealed that ALT and AST were within normal range with no statistically significant difference between the exposed and the control groups. This might be because the levels of organic solvents that were not so far from the standard permissible values. Our findings are also in line with Aminian et al., [20] in Iran who carried out a study to evaluate the hepatic damage due to exposure to organic solvents. The study reported there were no statistically significant difference between cases and controls.

In Iran 2015, a survey study on rubber industry workers exposed to a mixture of organic hydrocarbons including benzene, toluene and xylene reported that mean levels of ALT and AST in exposed workers were normal. Although, the exposure rate to each single chemical was within the permissible exposure limit, the mean of exposure to mixture of hydrocarbons was greater than the permissible exposure limit in some places [21]. Contrary to Hasani et al., [22] in Egypt that conducted a study on 63 workers in furniture manufacture occupationally exposed to mixture of solvents (mainly toluene, styrene and benzene) and 27 healthy controls. The study found that all parameters of liver function were high among exposed groups. Serum ALT was increased by increasing the duration of exposure "a sensitive biomarker for hepatic affection".

The rise of liver enzymes levels (AST, ALT) reflects damage of liver cells but, they are not sensitive enough for the diagnosis of early stages of occupational liver dysfunction. Therefore, some studies reported higher sensitivity of serum bile 
acids for diagnosis of liver dysfunction [23]. The difference between various studies might be due to different sample size, type of solvents, duration of exposure and application of safety measures in work place including use of protective equipment $[11,24]$. Also, several predisposing factors should be taken into consideration while assessing hepatotoxicity due to solvent exposure such as alcohol use, hepatotoxic drugs, genetic factors and obesity [25]. In the present study, rotation of workers between different departments of the rubber factory, increased absenteeism from work and less sensitivity of liver tests were the most important limitations of the study.

Conclusions: Environmental monitoring revealed higher levels of benzene, toluene and ethylbenzene. Total mean score for all items of check list of safety measures in the rubber factory was insufficient. Workers didn't receive any training programs about safe work practice. Liver function tests had normal levels for the majority of exposed workers.

Recommendations: Dissemination of these results to the head of the rubber factory and to the responsible managers to apply the suitable engineering and environmental controls to occupational exposures to chemicals, heat, noise, fumes and dust. Health education of workers about the hazards in rubber manufacturing $\&$ training them on safety measures. Make sure that workers follow safe work practices. Regular environmental monitoring and regular periodic medical examinations should be done for exposed workers.

\section{References}

1- STELLMAN J.M.: Encyclopaedia of occupational health and safety: International Labour Organization, 1998.

2- MALAGUARNERA G., CATAUDELLA E., GIORDANO M., NUNNARI G., CHISARI G., MALAGUARNERA M., et al: Toxic hepatitis in occupational exposure to solvents. World Journal of Gastroenterology: WJG, 18 (22): $2756,2012$.

3- SOYINKA O.O., ADENIYI F.A. and AJOSE O.A: Biochemical parameters of liver function in artisans occupationally exposed to "vat dyes". Indian Journal of Occupational. and Environmental. Medicine, 11 (2): 76, 2007.

4- BENICHOU C., DANAN G. and FLAHAULT A.: Causality assessment of adverse reactions to drugs-II. An original model for validation of drug causality assessment methods: Case reports with positive rechallenge. Journal of Clinical Epidemiology, 46 (11): 1331-6, 1993.

5- MARIA V. and VICTORINO R.: Development and validation of a clinical scale for the diagnosis of drug-induced hepatitis. Hepatology, 26 (3): 664-9, 1997.

6- WINDER C. and STACEY N.H.: Occupational toxicology: CRC press, 2004.
7- REESE C.D.: Occupational health and safety management: A practical approach: CRC Press, 2008.

8- SAFETY O. and ADMINISTRATION H.: Small business handbook: Government Institutes, 2008.

9- KHODER M.I.: Ambient levels of volatile organic compounds in the atmosphere of Greater Cairo. Atmospheric Environment, 41 (3): 554-66, 2007.

10- WHO Organization guidelines for indoor air quality: Selected Pollutants, 2010.

11- KAUKIAINEN A., VEHMAS T., RANTALA K., NURMINEN M., MARTIKAINEN R., TASKINEN H., et al.: Results of common laboratory tests in solvent-exposed workers. International Archives of Occupational and Environmental. Health, 77 (1): 39-46, 2004.

12- LEE N., LEE B-K., JEONG S., YI G.Y. and SHIN J.: Work environments and exposure to hazardous substances in Korean tire manufacturing. Safety and health at work, 3 (2): 130-9, 2012.

13- HASSAN A.A.E.H., ELNAGAR. S.A.E.M., EL TAYEB I. M., BOLBOL S.A.E.H.: Health hazards of solvents exposure among workers in paint industry. Open Journal of Safety Science and Technology, 3 (04): 87, 2013.

14- VERMEULEN R., DE HARTOG J., SWUSTE P. and KROMHOUT H.: Trends in exposure to inhalable particulate and dermal contamination in the rubber manufacturing industry: Effectiveness of control measures implemented over a nine-year period. Annals of Occupational Hygiene, 44 (5): 343-54, 2000.

15- ANN C.Y., LEE K.J., PARK J.B., JANG J.Y. and KIM M.J.: The association of exposure to organic solvents with liver function. Korean Journal of Occupational. and Environmental. Medicine, 13 (1): 64-74, 2001.

16- NIJEM K., KRISTENSEN P., THORUD S., AL-KHATIB A., TAKRORI F. and BJERTNES E.: Solvent exposures at shoe factories and workshops in Hebron City, West Bank. International Journal of Occupational and Environmental Health. 7 (3): 182-8.

17- HYEON C.K., CHUNG M.N., SUN H.J., KWANG H.H., OH D.K. and SUH I.: Normal serum aminotransferase concentration and risk of mortality from liver diseases: Prospective cohort study. BMJ, 328 (7446): 983, 2004.

18- MOHAMMADI S., MEHRPARVAR A., LABBAFINEJAD Y. and ATTARCHI M.S.: The effect of exposure to a mixture of organic solvents on liver enzymes in an auto manufacturing plant. Journal of Public Health, 18 (6): 553-7, 2010.

19-EL MAHDY N. and RADWAN N.: Assessment of different health hazards in painting industry. The Egyptian Journal of Occupational Medicine, 33 (2): 211-32, 2009.

20- AMINIAN O., SHARIFIAN A., JALALIE M., RAZI M. and MJ E.A.: Alterations of hepatic enzymes in industrial painters exposed to organic solvents in Tehran. Research in Medicine, 31 (3), 2007.

21- RAFEEMANESH E., BAZZAZ M.M., SADROSSADAT F. and AHMADI F.: A Survey on Chemical Hazards and Liver Function in Rubber Industry Workers in Iran. International Journal of Clinical Medicine, 6 (5): 347, 2015.

22- HASANI I.W., SHARAF N.E., EL-DESOUKY M.A., SHAKOUR A.A.A. and Mohamed M.S.: Hepatic impair- 
ment among workers of furniture manufacture occupationally exposed to solvents in Egypt. Journal of the Arab Society for Medical Research, 10 (2): 82, 2015.

23- NUNES DE PAIVA M and PEREIRA BASTOS DE SIQUEIRA M.: Increased serum bile acids as a possible biomarker of hepatotoxicity in Brazilian workers exposed to solvents in car repainting shops. Biomarkers, 10 (6): 456-63, 2005.
24- PRATT D.S. and KAPLAN M.M.: Evaluation of abnormal liver-enzyme results in asymptomatic patients. New England Journal of Medicine, 342 (17): 1266-71, 2000.

25- BRAUTBAR N. and WILLIAMS J.: Industrial solvents and liver toxicity: Risk assessment, risk factors and mechanisms. International Journal of Hygiene and Environmental Health, 205 (6): 479-91, 2002.

\section{تقييم التعرض المهنى اللمذيبات العضوية وإجراءات الوقاية ومدى تأثيرها

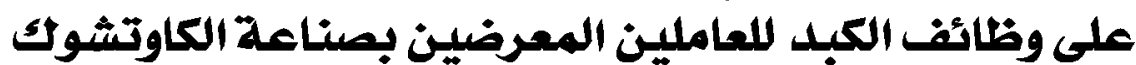 بمدينة طنطا - محافظة الفرفين لفيلية}

الهقدمة: هناك إستخدام واسع المذيبات العضوية فى العديد من الصناعات بما في ذلك صناعة المطاط التى قد تؤدى إلى مخاطر صحية مختلة للعمال وقد تئثر على البيئة المجاودة إذا لم يتم تطبيق تدابير السلامة بشكل صحيح.

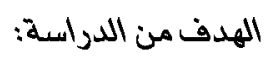

1- تقييم تدابير السلامة التى يتم تطبيقها فى مكان العمل. r - باس التعرض البيئى لبعض المذيبات العضوية فى مكان العمل. r- قياس وظائف الكبد للعمال المعرضين مهنياً للمذيبات العضوية فى صناعة المطاط. طريقة البحث: دراسة مقطعية عرضية أجريت على جميع العاملين فى جميع أقسام مصنع المطاط بمدينة طنطا (.r. (عامل) فى الفترة

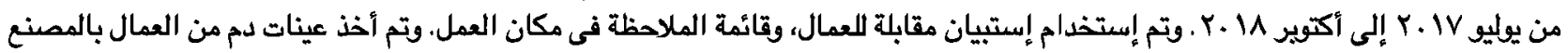
لقياس وظائف الكبد.

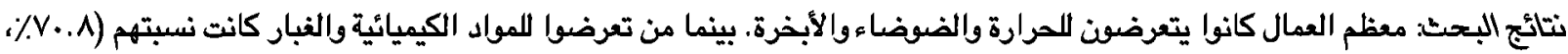

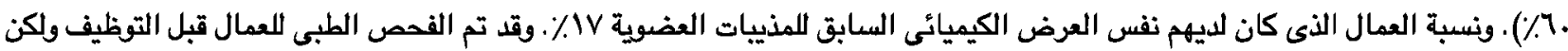

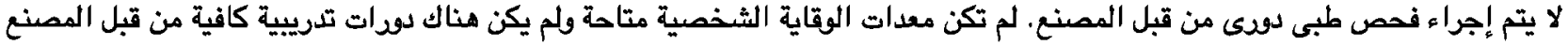

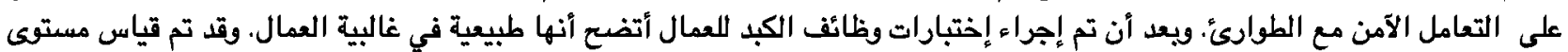

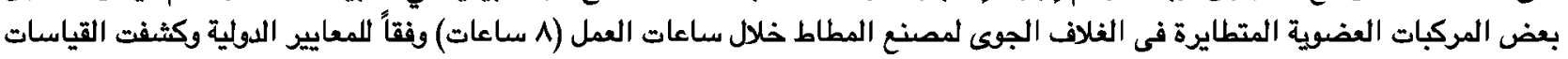

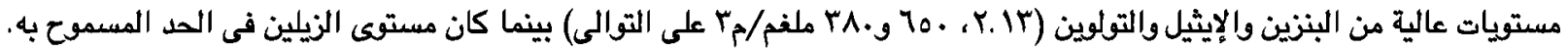
الخلاصة: أن التعرض المذيبات العضوية فى مصنع المطاط له تأثئير ضعيف على وظائف الكبد اللعاملين المعرضين على الرغم من مستويات عالية من بعض المذيات العضوية وأن أغلب الأقسام بالمصنع لم تكن كافية فيما يتعلق بتدابير السلامة. التوصيات:

1 - ينبغى تطبيق تدابير السلامة مع إستخدام ضوابط هندسية وبيئية مصممة تصميماً جيداً للتقليل إلى أدنى حد من التعرض المواد الكيميائية ومستويات الضوضاء الزائدة وتوفير التهوية الكافية.

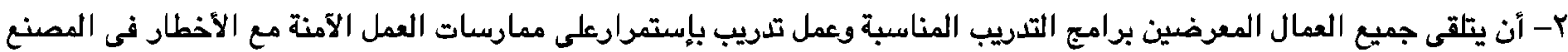

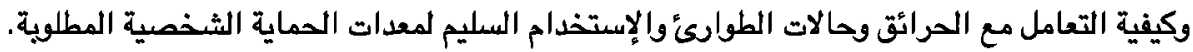

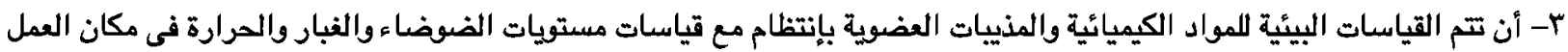
من خلال الطرق المناسبة. ع- إجراء الفحص الطبى الدورى بإنتظام كل 7 أثشر اللكشف المبكر عن أى مشاكل صحية. 